International Review of Research in Open and Distributed Learning Volume 17, Number 3

April - 2016

\title{
Blending Formal and Informal Learning Networks for Online Learning
}

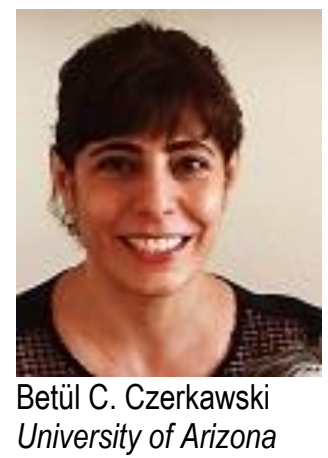

\section{Abstract}

With the emergence of social software and the advance of web-based technologies, online learning networks provide invaluable opportunities for learning, whether formal or informal. Unlike top-down, instructor-centered, and carefully planned formal learning settings, informal learning networks offer more bottom-up, student-centered participatory but somewhat disorganized learning opportunities for students. This paper presents a research study where graduate students are surveyed in their use of informal and formal learning networks in online courses to understand the interaction between the two and how they impact each other. The findings showed that students and professors use both environments often, to optimize learning but online course design is usually not designed to consider informal experiences of the students. The results and illustrated course design framework may contribute to the discussion of blending informal and formal learning for online learning.

\section{Introduction}

Today, life-long learning is crucial for gaining new knowledge and skills in an ever-changing society and it doesn't necessarily happen in formal education environments. As a matter of fact, the majority of adult learning occurs informally (Livingstone, 2000) and technology is key in attaining these experiences. Although informal learning is not a new concept, social technologies enabled new opportunities that were not possible in the past and even "blurred the distinction between formal and informal learning" (Dron \& Anderson, 2014, p.19). Many scholars (Czerkawski \& Hernandez, 2011; Dabbagh \& Kitsantas, 2012; Kassens-Noor, 2012; Veletsianos \& Navarrete, 2012) also emphasize the social nature of informal learning in the digital age, as student experiences are widely influenced by social technologies. For instance, 
today's students use instant messaging, visit websites, listen to music, play games, and download materials as a means of informal learning (Lai, Khaddage, \& Knezek, 2013), and all these methods are key for social interaction.

Opinions vary in regards to differentiating formal and informal learning environments. Some scholars find difficulty differentiating as, "when learning takes place, elements of both informal and formal learning are present" (Manuti, Pastore, Scardigno, Giancaspro, \& Morciano, 2015, p.12). The advancement in network technologies and ubiquity of online courses has created an interwoven and intricate learning ecosystem that makes this differentiation even more difficult. Cox (2013), for instance, states that the distinction between informal leisurely activities and formal homework is becoming blurred due to teachers' abundant web-based teaching materials. On the other hand, Laurillard (2007) warns that formal and informal environments have very different contexts for learning and students should know the differences to use them effectively. In the new networked environments, it may be impractical to define what formal or informal learning is but instructors are now more than ever trying to understand the affordances of each to create effective learning designs.

In this study, our purpose is to look at the interactions between formal and informal learning networks in online courses in order to inform instructors and instructional designers. We begin our investigation with the description of formal and informal learning environments and learning networks. We then review empirical research trends, followed by an overview of research design and findings. The paper ends with the summary of conclusions along with an illustrated online course design framework. Our main goal is to provide new insights into the design of online instruction relevant to students' experiences and contribute to the discussions about blending formal and informal learning.

\section{Background}

The literature on the definition of formal and informal learning is controversial, ambiguous, and invites disagreements among researchers (Colley, Hodkinson, \& Malcolm, 2002). In general, formal learning refers to structured, pre-designed learning activities that are facilitated by an instructor while informal learning refers to unstructured, serendipitous, and in most cases, incidental learning (Czerkawski \& Hernandez, 2011). Formal learning usually happens in educational institutions and leads to a degree or certification whereas informal learning occurs leisurely outside the classroom and is not assessmentdriven.

As web-based social technologies become part of our lives, almost all students act on their personal or professional interests and become part of online learning networks. These networks are formed by connections between entities (Siemens, 2004) and learning networks refer to all technologies used to facilitate learning, whether informal or formal. Today's college students use them to gain and share knowledge. In most cases, however, it is the informal networks that foster more engaging, self-directed, and curiosity-based experiences (Dabbagh \& Kitsantas, 2012; Ghislandi, Ierardi, Leo, \& Spalazzi, 2013; Siemens, 2004). It may be that simply participating in these learning networks is not a means to an end but is in part an end, itself (Evans, 2015). Conversely, though higher education institutions are not 
programmed to fully understand learning networks (McCarthy, Miller, \& Skidmore, 2004), they have become a major point of interest due to concerns about retention, academic achievement, school completion, workplace preparedness, and students' dissatisfaction and disconnection from school (Greenhow \& Robelia, 2009).

Although the differences between formal and informal learning networks are clear, there are also many overlaps between them. A growing number of scholars (Johnson, Adams Becker, Estrada, \& Freeman, 2015; Jones \& Dexter, 2014; Lai et al., 2013) asserted that with the penetration of technologies in our daily lives, it is difficult to differentiate what is formal and what is informal, therefore a holistic approach to these two formats should be considered. Some scholars (Chatti, Agustiawan, Jarke, \& Specht, 2012; Dabbagh \& Kitsantas, 2012; Downes, 2010) suggested the use of personal learning environments (PLEs) to blend informal and formal learning networks. Personal learning environments constitute a mixture of web-based "tools, materials and human resources that a person is aware of and uses for life-long learning" (Marín-Juarros, Negre-Bennasar, \& Pérez-Garcias, 2014, p. 36) and could be seen as fine examples of learning networks. Through PLEs students can personalize their learning experiences, have full control over what they learn and connect with other peers and experts. Evans (2015) suggested PLEs "can be seen as the operationalization of connectivism" (p. 32), the key aspect being the reciprocity between participants rather than the authority or expertise held by one member.

Because of the flexibility and student control in PLEs they tend to represent more informal learning experiences and serve as a buffer between stagnant and instructor-centered online courses. Mott and Wiley (2009) suggested use of open learning networks (OLN) to eliminate limitations of course managements systems (CMS) that are used in almost all online courses. OLNs are hybrids of CMSs and PLEs "with the potential to leverage the affordances of the Web to improve learning dramatically" (Mott \& Wiley, 2009, p.3). Alternatively, others (Jones, Scanlon, \& Clough, 2013; Khaddage, Lanham, \& Zhou, 2009; Santos \& Ali, 2012), supported the use of mobile technologies since they are part of almost all college students' lives. Facer and Sandford (2010) suggested the creation of a curriculum that links formal and informal learning by including:

opportunities for learners to learn and work within meaningful socio-technical networks not wholly within single educational institutions; to be assessed in interaction with tools, resources and collaborators; to develop capacities to manage information and intellectual property, build reputation and trust, develop experience of working remotely and in mediated environments; to create new learning networks; to reflect upon how learning is connected with other areas of personal, social, and working lives and manage and negotiate these relationships; to explore the human-machine relationships involved in socio-technical networks (p.86).

Even though it is intriguing to integrate informal learning, there are challenges. First, all such efforts are confronted by the difficulty of precisely capturing students' personal experiences. Most higher education institutions do not have any structure or system that measures knowledge and skills gained outside formal environments. At the classroom level, instructors could interview the students or gain understanding through their observations but most efforts are not formally measured or quantified. 
Second, students engage in many online activities and interact in networks but not all of these are applicable to formal settings. For instance, after a decade long cross-country analysis within European countries the European Commission (2013) concluded that it is not easy and clear-cut to transfer students' prior learning experiences because knowledge and skills gained through informal learning are not tangible and transferable to formal settings. Their efforts demonstrated many countries' willingness to acknowledge students' prior experiences to enter higher education and they recommended national qualifications frameworks based on learning outcomes, so knowledge, skills and competencies that are transferable to formal settings could be easily identified. For online higher education environments, the European Commission's recommendation can be used as a guide when blending formal and informal learning networks.

In order to overcome challenges with blending formal and informal learning and effective curriculum design, instructional design principles may guide the online instructors. "Instructional design, as a field, deals with the learning and teaching processes and environments and ways to provide the most efficient and effective instructional experiences to the learners" (Czerkawski, 2013, p.10). Instructional design usually starts with the learner analysis and continues with the determination of instructional objectives, learning activities, and assessment procedures. This paper presented a framework to assist the instructional development process so online instructors can achieve quality of instruction.

\section{Review of Empirical Research Trends}

Informal and formal learning research is not new but, their situated context in web-based learning networks is relatively new. The ubiquity of the latest technologies and their use by today's students has significantly changed students' learning experiences, continuously mixing formal and informal environments. It is clear that understanding and harnessing social technologies used in learning networks is essential for designing effective and meaningful online courses. Some researchers (Greenhow \& Robelia, 2009) argued that there is a disconnect between formal and informal learning environments and formal learning falls short of training students in twenty-first century skills. In a qualitative study

conducted by Greenhow and Robelia (2009), the authors concluded that informal learning networks are effective when formulating and exploring various dimensions of a students' identity. The students that participated in the study have successfully developed twenty-first century skills as defined by International Society for Technology in Education (ISTE) (2007) as creativity, communication and collaboration, technological fluency, digital citizenship, problem solving, and research fluency. However, they perceived little connection between their formal learning experiences in the classrooms and informal use of learning networks. Another important finding of this study is that the advantages of social learning networks for academic and career networking were not clear to the participants who need them the most. Almost all students use these networks but little effort is made by the teachers to help students connect informal and formal experiences to their advantage. 
Greenhow and Robelia's (2009) research was conducted using minority students from low income families. There are other research trends that focused on the significance of technology access issues for elearning, merits of using learning networks, and student's ability to benefit from them (Cox, 2013). While most learning networks are available to all students, students with low socioeconomic status (SES)benefit less from informal learning. The reason for this is not necessarily related to access to technology but families' determination and motivation to use web-based networks and value their role in their children's learning. In this sense, technology doesn't remove pre-existing inequalities (Mardis, 2013). With the ubiquitous use of mobile technologies by college students Cox argued that it is not the physical access barrier that determines the digital divide in our times anymore but information literacy skills among students that create cognitive divide. Along the same lines, Fox (2013) argued that students' increasing access to information technology resources created an imbalance between formal and informal learning settings resulting in great variety in technological literacy among students. In other words, instructors and instructional designers no longer can predict the level of student experiences in informal learning networks to inform their online course design, because students come to formal learning settings with a wide range of experiences.

Another major research trend is about the role mobile technologies play in blending formal and informal learning environments. Mobile technologies, by providing anytime anywhere access to e-learning and learning networks, offer new possibilities for student access and enable collaborative, cooperative, and interactive learning. Lai et al. (2013) proposed the Mobile-Blended Collaborative Learning (MBCL) model where strengths of informal learning are used to mitigate weaknesses of formal learning, and vise versa. In this model, mobile tools for collaboration (e.g., Google Apps), coordination (e.g. Twitter), and communication (e.g., Skype, Facebook) created a balanced and flexible environment while blending synergistically formal and informal environments. Along the same lines, Marty et al. (2013) developed a mobile iPad app to foster students' online digital literacy skills. Using Hobbs's (2011) competencies, digital literacy skills are defined as access, analyze and evaluate, create, reflect, and act. The findings demonstrated that when technology is closely aligned with digital learning competencies and learning goals, it has the power to blend both learning environments. Cook, Pachler, and Bradley (2008) studied use of mobile technologies by college students and conducted interviews with their students to better understand how informal learning experiences carry to formal learning. In this qualitative case study, student narrative data pointed to two major themes: affective issues (perceptions, motivation, identity attached to mobile device, in this case the smartphone) and transfer to formal learning (collaboration with other students, networking for learning, group work). Students also stated the value of instructor prompts in bridging the informal and formal learning.

In terms of career advancement, instructors have increasingly turned to PLEs or personal learning networks (PLNs)-defined by Visser, Evering, \& Barrett (2014) as simply "a system of interpersonal connections and resources" (p. 396)-for myriad reasons. Through a mixed-methods study of academics across nine global, learning- or teaching-centered networks, Wakefield and Dismore (2015) established three major motivations behind academics' reasons for networking: "an intrinsic interest in pedagogy, pursuing collaborative public and career promotion” (p. 8). Through a collection of interviews, Pataraia, Margaryan, Falconer, and Littlejohn (2015) suggested it is access to and feedback from a diversified 
network of their peers, in part due to the perceived benefit in the inclusion of social networks in PLNs as a means of reinforcing desired qualities like "trust, reciprocity and community values" (p. 341) but also because academics may see the joining of these networks as a way to fit perceived norms or expected roles within their field or university.

Within PLNs, instructors may also find the professional development (PD) superior to that of traditional methods that seem anachronistic or antiquated (Visser et al., 2014). One specific and growing example of PLEs or PLNs to provide current, meaningful PD is Twitter. Both a social network and a microblogging platform, Twitter has become a focus of PLN research in recent years, in due to its usefulness in PD (Tur \& Marín, 2014). While Visser et al. (2014) found teachers using Twitter in a professional capacity much more than in a personal one, Kist, Tollafield, and Dagistan (2014) warned that those interested in using Twitter for PD first consider seriously the purpose of their PD. Evans (2015) suggests that instructors are progressively likely to be self-driven in $\mathrm{PD}$, making the correct choice in which network to use to bolster identity within a profession all the more significant. Given sufficient participation in these networks, relationships akin to mentor and mentee may even develop (Rodesiler, 2015).

Among the important aspects of teachers choosing learning networks, optimization and evaluation are key. Ivanova, Grosseck, and Holotescu (2012), in a review of relevant literature, identified a number of considerations instructors should make to best use their time and energy. These include the following considerations: the creation of accurate, easily-locatable public profiles to facilitate peer discovery; identifying and maintaining an idea of the desired outcome of network participation; an awareness of his or her own learning methods and styles; an honest view of the network's norms; and an understanding of how to automate some networking tasks. By being cognizant of these five items, instructors will be more efficient at identifying, evaluating, and thereby effectively using networks for their own professional development and subsequent identification of and transfer into the classroom and formal and informal learning networks of their students.

Regarding instructors' use of formal and informal learning networks, there is a small amount of recent research. Chen and Bryer (2012), through qualitative interviews, studied instructor perspectives on using social networks for formal and informal learning. Their study showed informal networks were used mostly to enrich classroom discussions and online collaborations in higher education. All instructors also mentioned they and their students' use of networks for academic and career networking. With regard to the concerns, instructors cited cyber security, privacy, ethical issues, support, time constraints, and technology barriers as major obstacles for integration. Chen and Bryer argue that most online formal learning environments are delivered through a learning management system (LMS) and conventional LMSs offer limited opportunities for true integration of informal learning networks. Lack of connectivity and access to the outside world creates a major blockage for blending informal and formal learning settings.

Some researchers studied the learning strategies used by the students to compare informal and formal learning. In a recent study, Tan (2013) examined the students' search and evaluation strategies in informal learning environments, more specifically in YouTube, and how the knowledge gained in these 
networks transferred to a hybrid formal setting. The semi-structured interviews used in focus groups revealed a few interesting results. First, students still rely on their instructors to identify reliable and academically sound information for them. When the information is varied and abundant, they do not have the right skills to navigate and sift valid from invalid information. Furthermore, students expressed that informal networks provide valuable learning experiences for them but they still prefer and value formal learning settings. Tan argues the importance of supporting and scaffolding students for digital literacy without compromising learner control, enjoyment, and exploration of the informal settings.

Currently the literature acknowledges the importance of informal learning networks and the need for blending the two to create synergistic learning. Informal learning provides a true learner-centered environment where students control with whom they want to be peer up or what they want to learn. On the other hand, in a structured formal environment facilitated by the experts, students are motivated to learn new things and search for more in the informal settings. Clearly, both environments have their merits but there is little research on the interaction between formal and informal networks and more studies are needed "to investigate the extent and impact of informal uses of information technologies on formal e-learning” (Cox, 2013, p.17), which can help instructional designers develop effective online courses. Thus, the present study focuses on this interaction using a survey to generate new insights for the designers. The following research questions guided the study:

1. What formal and informal learning networks are most commonly used by the students and how?

2. What benefits and challenges exist in using formal and informal learning networks?

3. What is the relationship between formal and informal learning as seen by the students and online faculty?

\section{Research Design}

In this descriptive mixed-method case study, students $(n=27)$ and instructors $(n=8)$ were surveyed in their use of formal and informal learning networks. The students were graduate students attending an MS in Educational Technology and $\mathrm{PhD}$ in Second Language Acquisition programs, respectively, in a research university. Instructors were drawn from the faculty who are teaching in these programs. All but two of the students were experienced online learners taking two or more online courses during their studies and all but one of the instructors had experience teaching online courses. Parallel surveys with 17 items were developed for each participant group, including demographic, Likert-scale and open-ended questions. These questions were written after conducting a careful literature review. After securing the Institutional Review Board (IRB) consent, the surveys were distributed online using the Qualtrics survey program. Because of the low participation in the faculty survey, the results below were mainly summarized for the students. In the summary, research questions are used as a guide.

\section{Results}




\section{Formal and Informal Learning Networks Used by the Students and Instructors}

When asked about the most commonly used informal learning networks, student responses were quite similar: Facebook, Linkedin, Google+, YouTube, Delicious, Piazza, Twitter, Google Apps, Reddit, and professional networks and communities (Figure 1). For formal learning networks, students stated the use of similar programs and added various learning management systems and Coursera to the mix (Figure 2). Four students stated the use of social concept mapping programs as well. These responses show that students use similar learning networks both for formal and informal learning, and learning management systems and concept mapping provide more structure for formal learning.

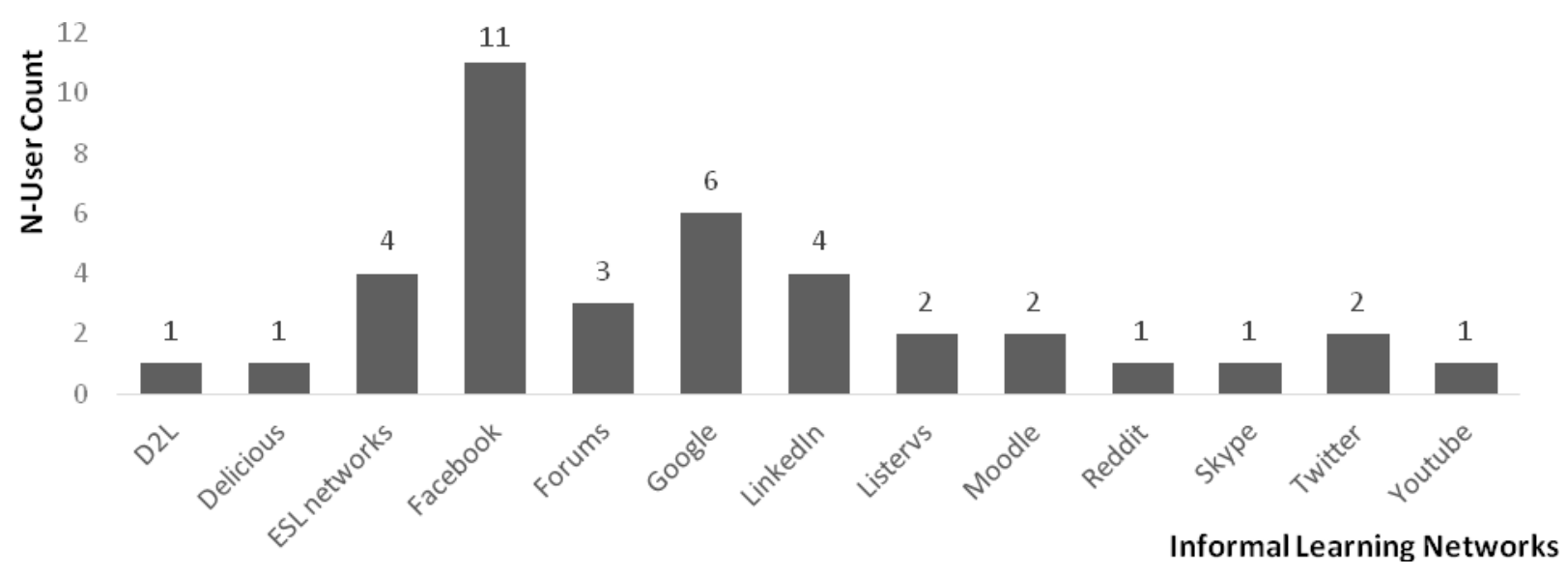

Figure 1. Informal learning networks identified by students. 


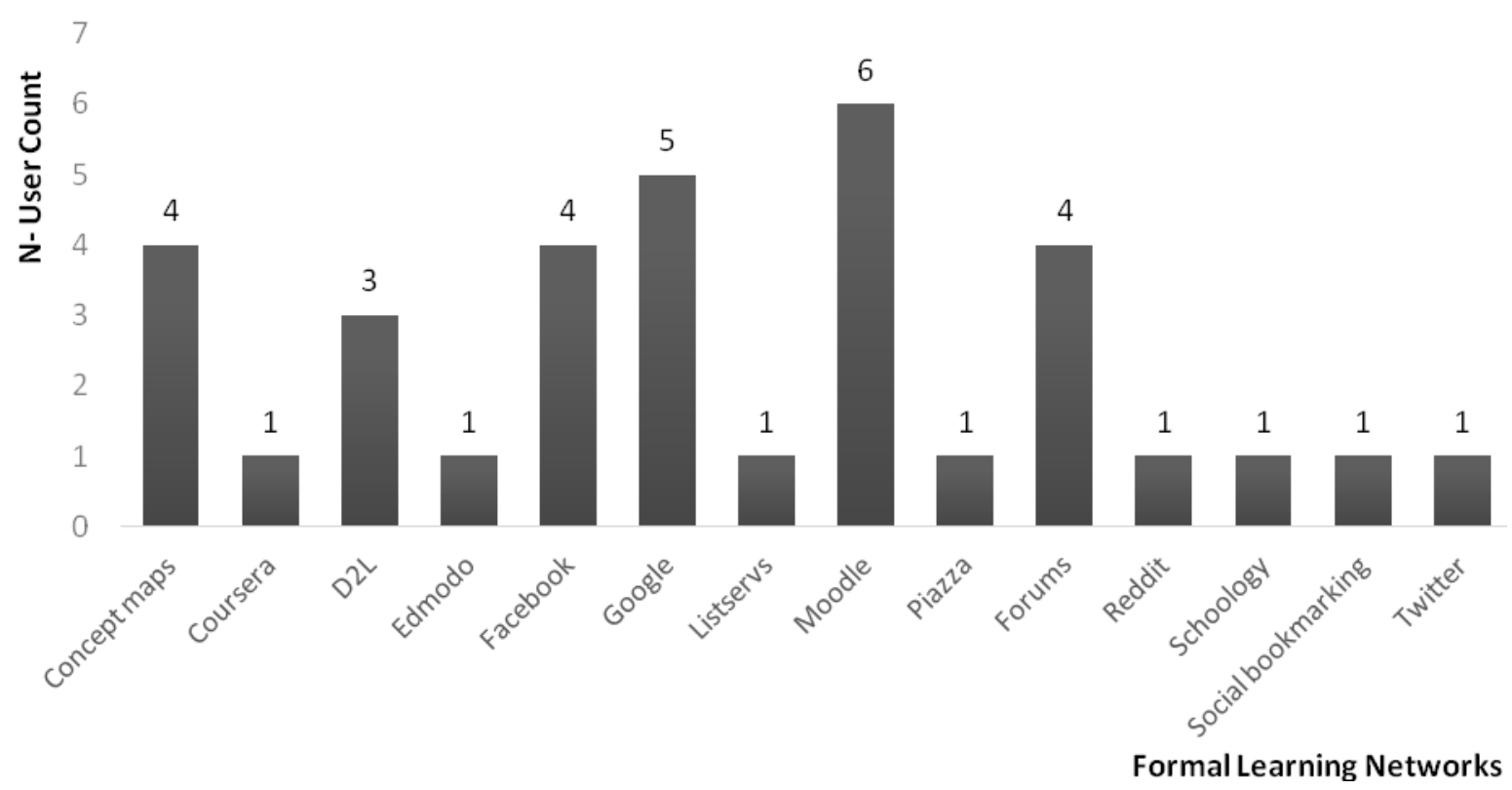

Figure 2. Formal learning networks identified by students.

When it comes to the self-reported roles played in the learning networks, the students also didn't express many differences between formal and informal learning networks (Figure 3). The majority of the students stated that they are members and active participants in the networks and they give feedback to the others in the network as well as asking them questions. Only a few students said that they either only lurk or lead the networks. 


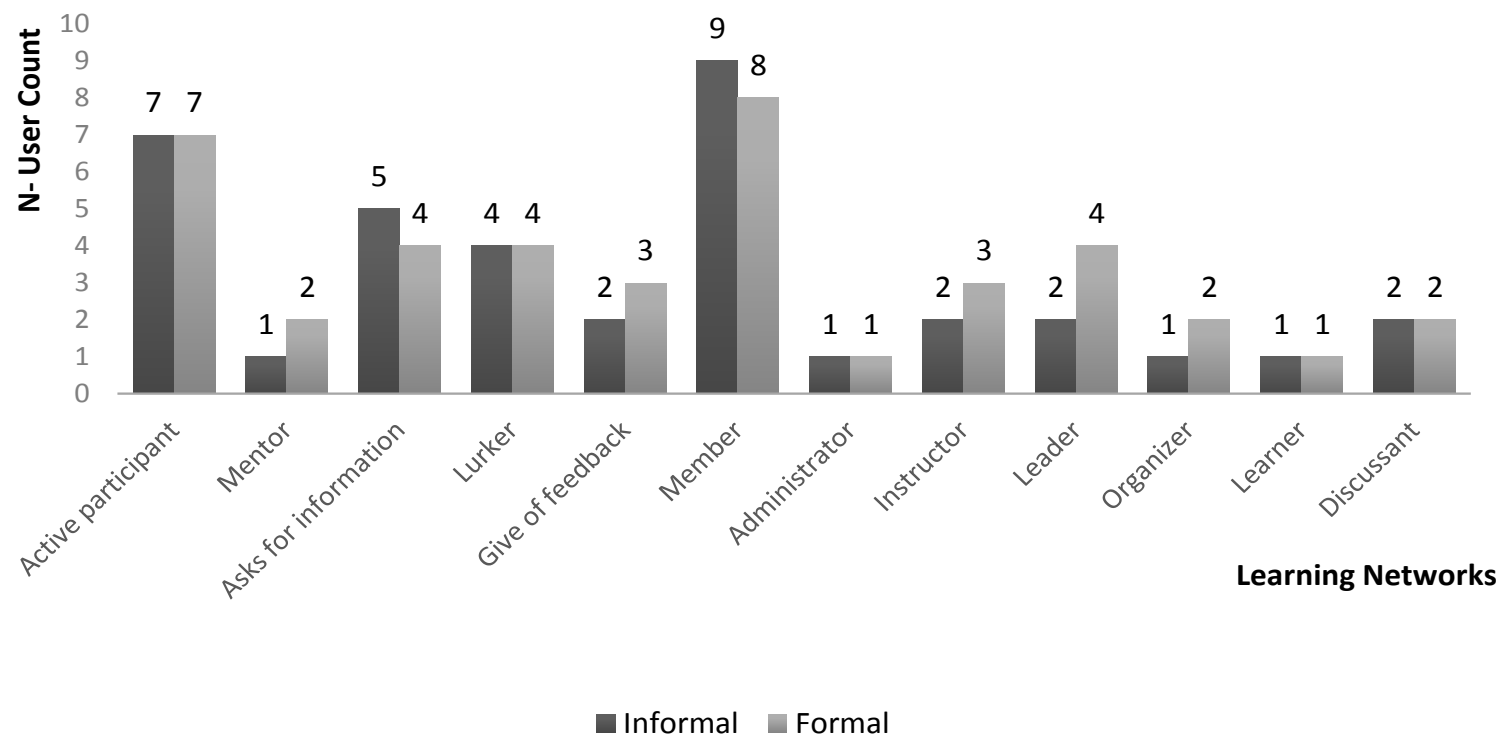

Figure 3. Students' roles in informal and formal learning networks.

In terms of frequency of usage, the vast majority of the students used virtual technologies to increase their learning experiences, they often used informal and formal learning networks and they saw high value in using learning networks (Table 1). Since most of these students also worked while pursing their degrees, they were asked whether their workplace supports use of learning networks. Their responses were evenly distributed from rarely to often. In another set of questions, the students responded to their experiences with formal learning networks and mentioned their instructors' support of learning network usage (Table 2). Finally, when asked about learning networks and success in professional settings, the students were undecided, with half of them responding sometimes.

Table 1

Percentage and Type of Student Informal Network Use

Questions

Never

Rarely

Sometimes

Often

How often do you use virtual technologies to advance your learning outside class?

$8.7 \% \quad 8.7 \% \quad 26.1 \%$

$56.5 \%$

How often do you use learning networks to advance your learning outside class?

$\begin{array}{lll}4.3 \% & 17.4 \% \quad 39.1 \%\end{array}$

$39.1 \%$

Do you see value in using learning networks outside the classroom?

$4.3 \% \quad--\quad 52.2 \%$

$43.5 \%$ 
Does the use of informal learning networks enhance your learning in formal environments?

Does your workplace encourage you to use learning networks? ${ }^{a}$
$4.3 \%$

$4.3 \%$

$4.3 \%$

Note. ${ }^{\text {a }}$ One student responded N/A.

The instructor survey yielded similar results as the student survey with two exceptions: the inclusion of podcast subscriptions and research networks such as Research Gate and Academia.edu. All instructors listed long lists of networks that focus on their research interests such as CMAP, MLA Commons, and FLTeach. When asked about the informal networks instructors recommend their students use, the results were nearly identical to the informal networks the instructors use, themselves.

Table 2

Percentage and Type of Student Formal Network Use

\begin{tabular}{lcccc}
\hline Questions & Never & Rarely & Sometimes & Often \\
\hline $\begin{array}{l}\text { How often do you use virtual technologies to advance your } \\
\text { learning in the classroom? }\end{array}$ & $5.3 \%$ & $10.5 \%$ & $31.6 \%$ & $52.6 \%$ \\
$\begin{array}{l}\text { How often do you use [formal] learning networks to } \\
\text { advance your learning outside class? }\end{array}$ & $5.3 \%$ & $10.5 \%$ & $36.8 \%$ & $47.4 \%$ \\
$\begin{array}{l}\text { Do you see value in using [formal] learning networks in the } \\
\text { classroom? }\end{array}$ & -- & $5.3 \%$ & $47.4 \%$ & $47.4 \%$ \\
$\begin{array}{l}\text { Do your instructors encourage you to use [formal] learning } \\
\text { networks? }\end{array}$ & -- & $10.5 \%$ & $31.6 \%$ & $57.9 \%$ \\
$\begin{array}{l}\text { Does your workplace encourage you to use [formal] } \\
\text { learning networks? }\end{array}$ & $5.3 \%$ & $5.3 \%$ & $47.4 \%$ & $31.6 \%$ \\
\hline
\end{tabular}

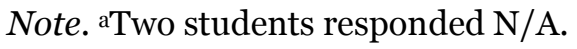

\section{Benefits and Challenges of Using Learning Networks}

In this study, students were asked about their opinions on the benefits and challenges of using learning networks using open-ended questions. For the benefits, they stated that in the formal learning networks, they learn from other people they wouldn't have access to otherwise. One student said that "through international connections, distant experts and colleagues, getting diverse perspectives is one of the most valuable benefits to me.” They listed knowledge gathering, collaborations, building connections, learning from others, brainstorming, and reflection as other benefits of formal networks. For the benefits of 
informal learning networks, students mentioned similar benefits to formal learning networks but this was also where the results significantly differed. One student said "I use informal learning networks to learn about things that interest me. It's more about getting ideas than collaboration, cooperation or application of knowledge." A few students mentioned the anonymity of informal learning networks and one said "In informal networks there are no requirements for what needs to be accomplished so I can customize who I speak with depending on what I need to learn.” A few other students mentioned the importance of being connected with those in the field and one student stated that "For me, it is mostly helpful just to have the community there to turn to if I need it, as well as to keep up with what is happening and relevant."

When asked about challenges with the learning networks, students expressed diverse opinions. For formal learning networks, students stated that diversity of opinions is an issue since there is usually one expectation from all students. Related to this issue, a few students mentioned the validity, reliability, and quality of the opinions expressed in formal networks and stated that the bias of those who are most vocal in the networks could be troubling. A few other students found the formal networks less engaging. One said that "Sometimes it is less motivating since it is required for the class, and content can be less interesting since students are forced to use it and sometimes I write fluff to meet the minimum requirement." Devoting enough time was also expressed as an issue. For formal networks that are out of one's institution, one student said this: "The time spent for the webinars are bizarre and inaccessible for me. I feel at a distance and with little motivation for prioritizing them. If my own program were to make these I feel I would be more likely to feel connected to these people I know in real life and attend or record later."

In regard to the informal learning networks and their disadvantages, most student comments focused around two issues: time needed to filter through unnecessary information and finding the relevant network that meets one's needs. For the first issue, one student noted: "it is like TMI: each contribute so many links to good sources that it is overwhelming, I've read the first paragraph of far too many sites with much to offer and never get back to them." A slightly different comment is made by another student: "There is often a lot of information and opinions that are not relevant or interesting to me, and this can bog down my time -leading to distractions or a desire to engage less in the community." Students also mentioned that often they don't know which networks to join and it takes time to be part of an active community. Finally, one student mentioned the limitations with multi-modality: "One must choose words wisely in order to be understood correctly."

\section{Interaction between Formal and Informal Learning Networks}

The survey included two questions, one closed- and one open-ended, about the interaction between formal and informal learning networks. When students asked about the impact of informal learning networks usage on learning in the formal networks, 22 of them stated a positive impact. Their open-ended responses also supported these findings, and many students thought that their experiences in the informal learning networks augmented their formal learning experiences. One student mentioned that his experiences in informal learning networks are helpful to bring back to formal settings and share what he has learned there. Another student said that "My informal ones inform me as to what I want to get in the 
formal ones. They help me set my expectations." Two students found formal and informal networks completely separate and one student expressed poorness of formal networks: "I think these informal networks make the formal ones seem duller, since I have so much more freedom within informal networks and can use them as needed."

\section{Conclusions and Discussion}

Though small, this study did derive some conclusions. The students surveyed use established learning networks in and out of the classroom and were well aware of the advantages and disadvantages of both environments. They received encouragement from their instructors to use learning networks and in most courses they were required to use various learning networks. What was lacking though is instructors' effort to blend informal and formal network usage. Furthermore, they received no guidance or scaffolding for their informal learning network use from their instructors. Their workplace did not present any pressure for usage, either.

There are many inadequacies of formal learning environments that don't fit into today's increasingly demanding workplace. Learning networks, especially informal ones, carry opportunities for selfregulated, autonomous, and engaging learning opportunities while offering the most current, authentic, and diverse knowledge and skills. It is important to adapt them in formal settings so students can integrate their prior and current learning experiences gained outside of formal classrooms with higher education courses. Conversely, it should also be remembered that while informal learning networks are beneficial for students, they are not designed with formal education in mind. One of the important findings of this study is that both learning formats have benefits and challenges. In order to effectively design online courses to take advantage of both learning formats, their affordances and constraints should be understood by the instructors who can then bridge the gap. However, further thinking and reflection is needed for teaching.

From an instructional design standpoint, the major issue is to understand learning opportunities provided by both formal and informal education networks and develop learning environments for various learning goals, needs, and situations. Online instruction has the potential to bring together informal and formal learning experiences in social learning networks while serving as an ideal platform for experimentation. This study provided views of college students and professors on informal and formal learning networks and, though the small sample size posed a limitation, most of the expressed opinions can easily be observed in other online college classrooms. Furthermore, the review of the research literature demonstrated that formal and informal learning experiences and their blend is popular among scholars, mostly whose interest is on mobile learning, digital literacy issues, and identity-related implications of learning networks. What was lacking is clear illustration of how this could be done using instructional design principles. Table 3 provides a framework for the online instructors for blending formal and informal learning.

Table 3 
A Framework for Designing Online Courses for Informal-Formal Learning

\begin{tabular}{|c|c|c|c|}
\hline $\begin{array}{c}\text { Blending Informal } \\
\text { and Formal Learning } \\
\text { Networks }\end{array}$ & Instructional Objectives & Learning Activities & Assessments \\
\hline $\begin{array}{ll} & \text { Personal } \\
\text { Interests / } \\
\text { Professional } \\
\text { Goals }\end{array}$ & 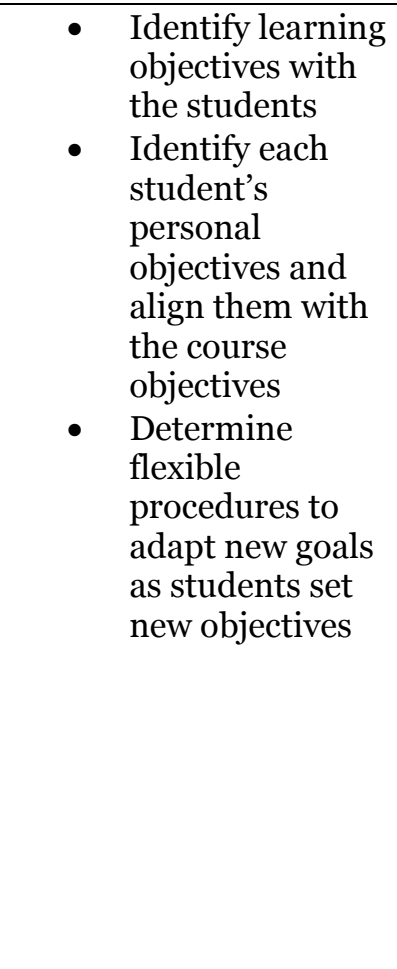 & $\begin{array}{l}\text { - Create individual } \\
\text { profiles on } \\
\text { professional sites } \\
\text { (e.g. Linkedin, } \\
\text { Research Gate, } \\
\text { Google Scholar) } \\
\text { Use Social } \\
\text { Calendar program } \\
\text { to set up group } \\
\text { goals } \\
\text { Identify learning } \\
\text { and professional } \\
\text { networks that are } \\
\text { compatible with } \\
\text { established } \\
\text { learning } \\
\text { objectives } \\
\text { Each student } \\
\text { creates an online } \\
\text { multimedia } \\
\text { database that } \\
\text { align with the } \\
\text { individual } \\
\text { learning goals }\end{array}$ & $\begin{array}{l}\text { Create personal } \\
\text { blogs/websites } \\
\text { to log learning } \\
\text { experiences } \\
\text { Include regular } \\
\text { formative } \\
\text { assessments for } \\
\text { individual and } \\
\text { peer progress }\end{array}$ \\
\hline $\begin{array}{l}\text { - Social } \\
\text { Interaction } \\
\text { and } \\
\text { Communicati } \\
\text { on }\end{array}$ & $\begin{array}{l}\text { Discuss } \\
\text { expected } \\
\text { individual and } \\
\text { group goals and } \\
\text { appropriate } \\
\text { learning } \\
\text { networks for } \\
\text { these goals } \\
\text { Discuss best } \\
\text { roles for each } \\
\text { student in the } \\
\text { learning } \\
\text { networks }\end{array}$ & $\begin{array}{l}\text { - Students interact } \\
\text { in their selected } \\
\text { learning networks } \\
\text { and report back to } \\
\text { class } \\
\text { - Communicate } \\
\text { with experts to } \\
\text { gain perspective } \\
\text { - Integrate class } \\
\text { activities with the } \\
\text { learning networks }\end{array}$ & $\begin{array}{l}\text { Discuss } \\
\text { feedback } \\
\text { received in the } \\
\text { learning } \\
\text { networks } \\
\text { - Examine roles } \\
\text { of each students } \\
\text { in learning } \\
\text { networks and } \\
\text { how they } \\
\text { worked for their } \\
\text { goals } \\
\text { Discuss } \\
\text { strategies to } \\
\text { validate } \\
\text { information in } \\
\text { informal } \\
\text { learning } \\
\text { networks }\end{array}$ \\
\hline
\end{tabular}


- Reflection and Metacognition
- Identify self and peer evaluation methods in each learning network
- Discuss peer and individual feedback strategies and select the most effective ones for individual students
- Reflect on valuable informal learning experiences and ways to share them with the class

As seen in Table 3, instructional design offers a comprehensive view of the issue by leveraging learning network technologies and pedagogical design considerations equally and simultaneously. Setting instructional goals and determining appropriate learning networks for the selected goals is the starting point in this framework. These goals need to be selected for individual students and room for diversity should be allowed in the curriculum. Depending on the goals, students may have differing roles in learning networks and attention should be paid to accommodate a wide range of roles. Most interaction and communication activity in learning networks occurs outside of the classroom but discussing and sharing those experiences should be part of the classroom activity. At every level, reflection and evaluation activities should be included to discuss, examine, and evaluate information or experiences gained in the networks. One of the most important parts of this framework is scaffolding. It will be the instructors' guidance, assistance, and modeling that will help students stay on track and monitor their learning progress. In addition to the instructors, experts outside the classroom can also guide students in their exploration and inquiry.

Clearly, most college classrooms-online or traditional-may not have room for such a flexible and student-centered approach. Not every learning outcome could be achieved using this framework, either. However, in every course a unit of instruction could be devoted for such experiences as a starting point and, depending on the outcomes, more integration activities could be added. More experimentation and empirical research may lead to the creation of a full-fledged model for online instruction.

Although course level frameworks are important, Lai et al. (2013) suggest that "school-wide policies highlighting the relationship between formal and informal learning in relation to technologies have to be developed, involving all the stakeholders in diverse educational contexts" (p. 421). With the support and involvement of the stakeholders, lasting changes to the curriculum could be made. In addition, more research studies that evaluate student experiences in the informal learning networks are needed. These studies could also serve as a selling-point for the stakeholders.

\section{References}

Chatti, M. A., Agustiawan, M. R., Jarke, M., \& Specht, M. (2012). Toward a personal learning environment framework. In M. Thomas (Ed.) Design, Implementation, and Evaluation of Virtual Learning Environments (pp. 20-40). Hershey, PA: IGI Global. 
Chen, B., \& Bryer, T. (2012). Investigating instructional strategies for using social media in informal and formal learning. The International Review of Research in Open and Distance Learning, 13(1), 87-104. Retrieved from http://www.irrodl.org/index.php/irrodl/article/view/1027.

Colley, H., Hodkinson, P., \& Malcolm, J. (2002). Non-formal learning: Mapping the conceptual terrain. A Consultation Report, Leeds: University of Leeds Lifelong Learning Institute. Also available in the informal education archives: http://www.infed.org/archives/etexts/colley informal learning.htm.

Cook, J., Pachler, N., \& Bradley, C. (2008) Bridging the gap? Mobile phones at the interface between informal and formal learning. Journal of the Research Center for Educational Technology, 4(1), 3-18.

Cox, M. J. (2013). Formal to informal learning with IT: Research challenges and issues for e-learning. Journal of Computer Assisted Learning, 29(1), 85-105.

Czerkawski, B. (2013). Instructional design for computational thinking. In R. McBride \& M. Searson (Eds.), Proceedings of Society for Information Technology \& Teacher Education International Conference 2013 (pp. 10-17). Chesapeake, VA: Association for the Advancement of Computing in Education (AACE).

Czerkawski, B., \& Hernandez, J. (2012) Formal, non-formal, informal E- Learning experiences with emerging technologies: A case study of a graduate educational technology program. In Yang, $\mathrm{H}$. \& Wang, Y. (Ed). Cases on formal, non-formal, and informal learning: Opportunities and practices. Hershey, PA: IGI Global.

Dabbagh, N., \& Kitsantas, A. (2012). Personal learning environments, social media and self-regulated learning: A natural formula for connecting informal and formal learning. Internet \& Higher Education, 15, 3-8.

Downes, S. (2010). New technology supporting informal learning. Journal of Emerging Technologies in Web Intelligence, 2(1), 27-33.

Dron, J., \& Anderson, T. (2014). Teaching crowds: Learning and social media. Edmonton, AB: Athabasca University Press.

European Commission, Education, Audiovisual and Culture Executive Agency. (2013). Recognition of prior non-formal and informal learning in higher education (Catalog No. EC-02-13-202-EN-N). Retrieved from http://eacea.ec.europa.eu/education/eurydice/documents/focus-on/152.pdf

Evans, P. (2015). Open online spaces of professional learning: Context, personalisation and facilitation. TechTrends, 59(1), 31-36. 
Facer, K., \& Sandford, R. (2010). The next 25 years? Future scenarios and future directions for education and technology. Journal of Computer Assisted Learning, 26(1), 74-93.

Fox, M. J. (2013). Formal to informal learning with IT: Research challenges and issues with e-learning. Journal of Computer-Assisted Learning, 29(1), 85-105.

Ghislandi, P., Ierardi, M. G., Leo, T., \& Spalazzi, L. (2013). Guest editorial: Innovative technologies for the seamless integration of formal and informal learning. Educational Technology \& Society, 16(1), $1-3$.

Greenhow, C., \& Robelia, B. (2009). Informal learning and identity formation in online social networks. Learning, Media and Technology, 34, 119-140.

Hobbs, R. (2011). Empowering learners with digital and media literacy. Knowledge Quest, 39(5), 12-17. Retrieved from http://www.ala.org/aasl/sites/ala.org.aasl/files/content/aaslpubsandjournals/knowledgequest/d ocs/KNOW 395 EmpoweringLearners.pdf

International Society for Technology in Education. (2007). ISTE standards for students. Retrieved from http://www.iste.org/standards/iste-standards/standards-for-students

Ivanova, M., Grosseck, G., \& Holotescu, C. (2012). Analysis of personal learning networks in support of teachers presence optimization. In Proceedings of the PLE Conference 2012, July 11-13, 2012. Retrieved from http://revistas.ua.pt/index.php/ple/article/view/1439/1325

Johnson, L., Adams Becker, S., Estrada, V., \& Freeman, A. (2015). New Media Consortium (NMC) Horizon Report: 2015 Higher Education Edition. Austin, TX: New Media Consortium.

Jones, A. C., Scanlon, E., \& Clough, G. (2013). Mobile learning: Two case studies of supporting inquiry learning in informal and semi-formal settings. Computers \& Education, 61, 21-32.

Jones, W.M., \& Dexter, S. (2014). How teachers learn: The roles of formal, informal and independent learning. Educational Technology Research and Development, 62, 367-384. doi: 10.1007/s11423-014-9337-6

Kassens-Noor, E. (2012). Twitter as a teaching practice to enhance active and informal learning in higher education: The case of sustainable tweets. Active Learning in Higher Education, 13(1), 9-21.

Khaddage, F., Lanham, E., \& Zhou, W. (2009). A mobile learning model for universities: Re-blending the current learning environment. International Journal of Interactive Mobile Technologies, 3(1), $18-23$.

Kist, W., Tollafield, K. A., \& Dagistan, M. (2014). Leading ourselves (tweets optional). Journal of Adolescent \& Adult Literacy, 58(4), 317-326. doi:10.1002/jaal.362 
Lai, K. W., Khaddaget, F., \& Knezek, G. (2013). Blending student technology experiences in formal and informal learning. Journal of Computer Assisted Learning, 29, 414-425. doi: 10.1111/jcal.12030

Laurillard, D. (2007). Pedagogical forms for mobile learning: Framing research questions. In N. Pachler (Ed.), Mobile learning: Towards a research agenda (pp.153-175). London, UK: WLE Centre, IoE.

Livingstone, D. (2000). Exploring the icebergs of adult learning: Findings of the first Canadian survey of informal learning practices. Canadian Journal for the Study of Adult Education, 13(2), 49-72.

Manuti, A., Pastore, S., Scardigno, A. F., Giancaspro, M. L., \& Morciano, D. (2015). Formal and informal learning in the workplace: A research review. International Journal of Training and Development, 19(1), 1-17.

Mardis, M. A. (2013). What it has or what it does not have? Signposts from US data for rural children's digital access to informal learning. Learning, Media and Technology, 38(4), 387-406.

Marín-Juarros, V. I., Negre-Bennasar, F., \& Pérez-Garcias, A. (2014). Construction of the foundations of the PLE and PLN for collaborative learning. Comunicar, 21(42), 35-43. doi:10.3916/C42-2014$\underline{03}$

Marty, P. F., Alemanne, N. D., Mendelhall, A., Maurya, M., Southerland, S. A., Sampson, V., ... \& Schellinger, J. (2013). Scientific inquiry, digital literacy, and computing in informal learning environments. Learning, Media and Technology, 38(4), 407-428.

McCarthy, H., Miller, P., \& Skidmore, P. (2004). Network logic. In H. McCarthy, P. Miller, \& P. Skidmore (Eds), Network logic: Who governs in an interconnected world? (pp. 11-22). London, UK: Demos.

Mott, J., \& Wiley, D. (2009). Open for learning: The CMS and the open learning network. In Education, 15(2), 3-22. Retrieved from http://ineducation.couros.ca/index.php/ineducation/article/view/53/530

Pataraia, N., Margaryan, A., Falconer, I., \& Littlejohn, A. (2015). How and what do academics learn through their personal networks. Journal of Further and Higher Education, 39(3), 336-357. doi:10.1080/0309877X.2013.831041

Rodesiler, L. (2015). The nature of selected English teachers' online participation. Journal of Adolescent \& Adult Literacy, 59(1), 31-40. $\underline{\text { doi:10.1002/jaal.427 }}$

Santos, I. M., \& Ali, N. (2012). Exploring the uses of mobile phones to support informal learning. Education and Information Technologies, 17(2), 187-203. 
Siemens, G. (2004, December 12). A learning theory for the digital age. elearnspace. Retrieved from http://www.elearnspace.org/Articles/connectivism.htm

Tan, E. (2013). Informal learning on YouTube: Exploring digital literacy in independent online learning. Learning, Media and Technology, 38(4), 463-477.

Tur, G., \& Marín, V. I. (2014). Enhancing learning with the social media: Student teachers' perceptions on Twitter in a debate activity. Journal of New Approaches in Educational Research, 4(1), 46-43. doi:10.7821/naer.2015.1.102

Veletsianos, G., \& Navarrete, C. C. (2012). Online social networks as formal learning environments: Learner experiences and activities. The International Review of Research in Open and Distance Learning, 13(1), 144-166. Retrieved from http://www.irrodl.org/index.php/irrodl/article/view/1078/2077.

Visser, R. D., Evering, L. C., \& Barrett, D. E. (2014). \#TwitterforTeachers: The implications of Twitter as a self-directed professional development tool for K-12 teachers. Journal of Research on Technology in Education, 46(4), 396-413. doi:10.1080/15391523.2014.925694

Wakefield, K., \& Dismore, H. (2015). The role of transnational networking for higher education academics. Higher Education Research \& Development, 34(6), 1281-1296.

doi:10.1080/07294360.2015.1024630

\section{Athabasca University}

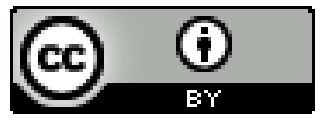

